\title{
ACE gene polymorphism and serum ACE level with Progression of Nephropathy in Type 2 Diabetic Patients
}

\author{
Olfat Gamil Shaker ${ }^{a^{*}}$, Manal Fouad Ismail ${ }^{b}$, Esmat Ashour ${ }^{c}$, Heba Mourad Yousif ${ }^{d}$, Mie \\ Afifyc, Weaam Gouda ${ }^{c}$ \\ ${ }^{a}$ Medical Biochemistry Dept., Faculty of Medicine, Cairo University, Egypt \\ ${ }^{b}$ Biochemistry Dept., Faculty of Pharmacy, Cairo University, Egypt \\ ${ }^{\mathrm{c}}$ Biochemistry Dept., National Research Centre, Dokki, Giza, Egypt \\ ${ }^{\mathrm{d}}$ Internal Medicine Dept., Faculty of Medicine, Cairo University, Egypt
}

\section{ABSTRACT}

Background. One of the most common complications of diabetes mellitus (DM) is diabetic nephropathy (DN). Angiotensin- converting enzyme (ACE) gene was the first candidate gene of renin-angiotensin system (RAS) for predisposition to DN.

Objective. Investigation whether the ACE insertion/deletion (I/D) polymorphism is associated with Egyptian type 2 diabetic patients (T2DM) with nephropathy. In addition, the study investigated the relationship between variants of ACE I/D gene polymorphism and serum ACE level and the progression of nephropathy in Egyptian T2DM patients.

Methods. A total of 85 T2DM patients (45 with nephropathy and 40 without nephropathy) besides 45 healthy (nondiabetic) age-matched subjects were recruited in this study for comparison. The (I/D) polymorphism of the ACE gene was investigated using PCR and serum ACE levels were determined using ELISA.

Results. The frequency of ACE DD genotype and $D$ allele was significantly higher in DN patients when compared to control healthy subjects and diabetic patients without nephropathy. In addition our results showed a significant association between DD genotype of ACE gene and elevated serum ACE level.

Conclusion. The present study showing a strong association between the $D$ allele and/or DD homozygous of ACE gene and diabetic patients developed nephropathy. In addition, individuals with $D$ allele have higher levels of serum ACE compared to those having I allele. ACE gene polymorphism and serum ACE level may serve as a susceptibility biomarker for nephropathy in type 2 diabetic patients.

\section{Keywords}

Diabetic nephropathy(DN), Type 2 diabetes mellitus (T2DM), Angiotensin-converting enzyme(ACE), Gene polymorphism , Serum ACE levels.

\section{Council for Innovative Research}

\author{
Peer Review Research Publishing System
}

\section{Journal: Journal of Advances in Chemistry}

Vol. 9, No. 3

editorjaconline@gmail.com 


\section{INTRODUCTION}

One of the most common complications of diabetes mellitus (DM) is diabetic nephropathy (DN), a progressive and irreversible kidney disease that occurs because of DM ${ }^{[1]}$. In Egypt the prevalence of nephropathy ranged from $6.7 \%$ in hospital outpatient clinics to $46.3 \%$ in hospital inpatients ${ }^{[2]}$. Clinically, diabetic nephropathy (DN) is characterized by a progressive increase in proteinuria, declining glomerular filtration rate (GFR) and an elevation of arterial blood pressure ${ }^{[3 \text {; }}$ 4]. The pathogenesis of diabetic nephropathy is not yet clearly understood, but available data suggest that multiple factors contribute to this complication. Poor glycemic control, metabolic abnormalities, hemodynamic alterations, hypertension, and genetic factors are the major contributing factors ${ }^{[5] .}$ Studies of familial clustering suggest that genetic predisposition plays a role in the development of diabetic nephropathy ${ }^{[6]}$.

Among the genes that have been evaluated as possibly conferring susceptibility to advanced nephropathy, the angiotensin-converting enzyme (ACE) gene is the most scrutinized. Studies of the ACE (I/D) polymorphism have primarily focused on whether the disease is associated with I/D of a 287-bp Alu sequence located in intron $16^{[7]}$. Emphasis was placed on this particular polymorphism since its $D$ allele has been linked to high levels of serum ACE ${ }^{[8]}$, a risk factor for diabetic nephropathy. Conflicting findings in various populations have been obtained with regard to the role of ACE (I/D) polymorphism in diabetic nephropathy ${ }^{[9 ; 10 ; 11]}$ and in type 2 diabetes ${ }^{[12 ; 13]}$ that might be attributed to the ethnic differences.

\section{OBJECTIVE}

To our knowledge, no enough data are available concerning the association of ACE gene polymorphism with nephropathy in T2DM Egyptian patients. Therefore the current study aimed, to analyze the polymorphisms I/D within ACE gene, and evaluate their contribution to susceptibility to nephropathy in T2DM patients. In addition, we studied the relationship between variants of ACE I/D gene polymorphism, serum ACE level and progression of nephropathy in type 2 diabetic patients.

\section{PATIENTS AND METHODS:}

\section{1) Study subjects}

This study recruited 85 T2DM patients diagnosed at least 5 years before, the patients consecutively attended the diabetes clinic of Internal Medicine Department; Kasr El-Aini Hospital affiliated to Cairo University. Forty five of them (12 males and 33 females) with nephropathy, while the remaining 40 (9 males and 31 females) without nephropathy. The mean age of T2DM patients with nephropathy was $48.47 \pm 8.89$ years compared to $54.43 \pm 8.45$ years for the T2DM patients without nephropathy. The diagnosis of T2DM was based on the American Diabetes Association criteria, a fasting plasma glucose level $>126 \mathrm{mg} / \mathrm{dL}$ and glycated hemoglobin $>6.5 \%$ and/or treated by oral hypoglycemic agents and/or insulin to achieve glycemic control. Diabetic nephropathy was defined by persistent albuminuria (albumin-creatinine ratio $[A C R]>30 \mathrm{mg} / \mathrm{g}$ creatinine) on at least two consecutive occasions over the previous six months. While patients with ACR $<30 \mathrm{mg} / \mathrm{g}$ creatinine were normoalbuminuric and had no nephropathy. To avoid misclassification diabetic individuals as having; abnormal liver function, abnormal thyroid function, advanced renal diseases other than diabetes, cardiovascular disease were excluded.

Beside 45 healthy subjects ( 17 males and 28 females) with mean age $51.04 \pm 7.97$ years and without any previous history of diabetes or renal disorders were enrolled as control group. The study protocol was approved by the Research Ethics Committee, Faculty of Pharmacy- Cairo University (REC-FOPCU). A written informed consent was obtained from each participant before testing.

\section{2) Sampling}

Venous blood was obtained from patients and controls after an overnight fast of $12 \mathrm{~h}$ and was divided into three portions. One portion of blood $(2 \mathrm{ml})$ was added to EDTA and stored at $-20{ }^{\circ} \mathrm{C}$ for detection of polymorphism of ACE gene and glycated hemoglobin assay. A second portion of $2 \mathrm{ml}$ blood was left for $10 \mathrm{~min}$ to clot and then centrifuged at $1000 \times \mathrm{g}$ for $5 \mathrm{~min}$; the serum was then separated and stored at $-20^{\circ} \mathrm{C}$ for determination of ACE levels. The last blood portion ( $1 \mathrm{ml}$ ) was added to Fluoride and centrifuged at $1000 \times \mathrm{g}$ for $10 \mathrm{~min}$; the plasma was then separated for determination of fasting plasma glucose.

Morning urine samples were collected under aseptic conditions from patients and controls. Urine was centrifuged at $500 \times \mathrm{g}$ to get rid of the cells and salts then the supernatant were used for determination of albumin and creatinine.

Serum ACE level and urinary albumin concentration were assessed using enzyme-linked immunosorbent assay (ELISA) kits provided from R\&D Systems and DRG-USA, respectively according to the manufacturer's protocol. Fasting blood glucose, glycated hemoglobin, urinary total protein and creatinine were measured using commercially available kits following the manufacturer's instructions.

\section{3) Isolation of genomic DNA}

Genomic DNA was isolated from peripheral white blood cells using Qia-amplification extraction kit (Qiagen-USA) according to the manufacturer's instructions. 


\section{4) Genotyping method for I/D polymorphism of ACE gene}

Genotyping was performed on extracted DNA by the polymerase chain reaction (PCR) using 5'CTGGAGACCACTCCCATCCTTTCT-3' as sense primer and

GATGTCGCCATCACATTCGTCAGAT-3' as antisense primer ${ }^{[7]}$. The reaction was performed with 5 pmol of each primer in combination with Taq PCR Master Mix (Qiagen, Valencia, CA, USA). The PCR cycling was performed with initial denaturation at $95^{\circ} \mathrm{C}$ for $5 \mathrm{~min}$ followed by 35 cycles of $94^{\circ} \mathrm{C}$ for $30 \mathrm{~s}, 50^{\circ} \mathrm{C}$ for $30 \mathrm{~s}, 72^{\circ} \mathrm{C}$ for $1 \mathrm{~min}$, and then by a final extension period at $72^{\circ} \mathrm{C}$ for 7 min (T-Gradient thermal cycler, Biometra, Germany).

Ten $\mu \mathrm{l}$ of the PCR products were analyzed on $2 \%$ agarose gels stained with Red-Safe, the PCR products were either 490 bps insertion (I allele) or 190 bps deletion (D allele) (Figure 2). The D allele is preferentially amplified in heterozygotes giving rise to mistyping of ID as DD in approximately $5 \%$ of cases. To avoid such mistyping, samples of DD genotype were subject to a second independent PCR with primers that recognize an insertion-specific sequence: 5'TGGGACCACAGCGCCCGCCACTAC-3' and 5'-TCGCCAGCCCTCCCATGCCCATAA-3' ${ }^{[14]}$ with identical PCR condition except for annealing temperature at $67^{\circ} \mathrm{C}$. Ten $\mu$ of the PCR products were analysed on $2 \%$ agarose gels stained with Red-Safe, the PCR reaction yields a 335 bp DNA product in the presence of the I allele, and no product for homozygous DD samples.

\section{STATISTICAL ANALYSIS}

Data are expressed as means \pm standard deviation for quantitative variables, frequency for qualitative variables. Quantitative variables were compared using independent Student t-test and One-way ANOVA. LSD test was used for multiple post-hoc comparisons. On the other hand, qualitative variables were compared using chi square $(x 2)$ test or Fischer's exact test. One-way ANOVA and Chi square test were used to compare the clinical and laboratory characteristics of patients divided according to genotypes. The Statistical Package for the Social Sciences software (SPSS 17.0, Chicago, IL, USA) was used. $\mathrm{P}<0.05$ was considered significant.

\section{RESULTS}

\section{Demographic and biochemical data of the studied groups:}

The demographic and clinical characteristics of type 2 diabetes patients with and without nephropathy and control groups are shown in Table 1. There were no statistical significant differences among studied groups regarding sex, insulin treatment, hypertension, and urinary creatinine. Regarding age there was significant differences among studied groups while, significant was lost between diabetic patients and control group. Diabetic patients with nephropathy had significantly higher fasting plasma glucose, glycated hemoglobin, urinary total protein, urinary albumin levels, albumin creatinine ratio, serum ACE level, and diabetic duration than the control and diabetic groups. Moreover, the poor diabetic control was significant risk factor for progression of nephropathy in diabetic patients.

Table 1: Demographic and clinical characteristics of all subjects.

\begin{tabular}{|c|c|c|c|c|}
\hline & $\begin{array}{c}\text { Control } \\
(n=45)\end{array}$ & $\begin{array}{l}\text { T2DM without } \\
\text { nephropathy } \\
(n=40)\end{array}$ & $\begin{array}{c}\text { T2DM } \\
\text { with nephropathy } \\
(\mathrm{n}=45)\end{array}$ & $\mathbf{P}$ \\
\hline \multicolumn{5}{|l|}{ Sex } \\
\hline Male & $17(37.8 \%)$ & $9(22.5 \%)$ & $12(26.7 \%)$ & \\
\hline Female & $28(62.2 \%)$ & $31(77.5 \%)$ & $33(73.3 \%)$ & $0.271^{* *}$ \\
\hline Age (years) & $51.04 \pm 7.97$ & $54.43 \pm 8.45$ & $48.47 \pm 8.89^{D}$ & $0.006^{*}$ \\
\hline Diabetes duration (years) & $\begin{array}{ll}-- \\
--\end{array}$ & $8 \pm 4$ & $10.98 \pm 4.8^{b}$ & $<0.001^{*}$ \\
\hline \multicolumn{5}{|l|}{ Treatment } \\
\hline Insulin & --- & $16(40 \%)$ & $26(57.8 \%)$ & \\
\hline Non-Insulin & --- & $24(60 \%)$ & $19(42.2 \%)$ & $0.078^{* * *}$ \\
\hline \multicolumn{5}{|l|}{ Pressure } \\
\hline Normal & --- & $27(67.5 \%)$ & $23(51.1 \%)$ & \\
\hline High & --- & $13(32.5 \%)$ & $22(48.9 \%)$ & $0.095^{\star * *}$ \\
\hline Fasting plasma glucose ( $\mathrm{mg} / \mathrm{dl})$ & $86.3 \pm 7.99$ & $246.3 \pm 76.1^{\mathrm{a}}$ & $289.3 \pm 98.35^{\text {ab }}$ & $<0.001^{\star}$ \\
\hline Glycated haemoglobin (\%) & $5.4 \pm 0.3$ & $8.786 \pm 1.45^{\mathrm{a}}$ & $9.92 \pm 1.95^{\mathrm{ab}}$ & $<0.001^{\star}$ \\
\hline
\end{tabular}




\begin{tabular}{|c|c|c|c|c|}
\hline \multicolumn{5}{|l|}{ Diabetic Control } \\
\hline Good & --- & $26(65 \%)$ & $18(40 \%)$ & \\
\hline Fair & --- & $10(25 \%)$ & $5(11.1 \%)$ & \\
\hline Poor & --- & $4(10 \%)$ & $22(48.9 \%)$ & $<0.001^{\star \star}$ \\
\hline Urinary total protein $(\mathrm{mg} / \mathrm{L})$ & $34.6 \pm 9.3$ & $97.2 \pm 50.3^{\mathrm{a}}$ & $449.8 \pm 130.3^{\mathrm{ab}}$ & $<0.001^{*}$ \\
\hline Urinary-albumin (mg/L) & $6.9 \pm 1.9$ & $13.97 \pm 9.96$ & $89.6 \pm 66.4^{\mathrm{ab}}$ & $<0.001^{\star}$ \\
\hline Urinary creatinine (g/L) & $1.05 \pm 0.27$ & $1.14 \pm 0.379$ & $0.98 \pm 0.437^{\circ}$ & $1.36^{*}$ \\
\hline Albumin creatinine ratio $(\mathrm{mg} / \mathrm{g})$ & $6.95 \pm 2.5$ & $12.95 \pm 9.03$ & $104.5 \pm 93.3^{\mathrm{ab}}$ & $<0.001^{*}$ \\
\hline Serum ACE level (ng/ml) & $92.8 \pm 34.4$ & $115.23 \pm 44.58^{\mathrm{a}}$ & $149.5 \pm 39.78^{\mathrm{ab}}$ & $<0.001^{*}$ \\
\hline
\end{tabular}

T2DM = Type 2 diabetes mellitus, ACE = Angiotensin converting enzyme.

Data are expressed as mean \pm SD for quantitative variable or number (\%) for qualitative one

*One way ANOVA test " "Chi square test "*** Fisher exact test

${ }^{a}$ Significantly different from control,

${ }^{\mathrm{b}}$ Significantly different from T2DM without nephropathy.

Bold values indicate significant difference

$P$ value $<0.05$ was considered significant.

\section{Serum ACE level}

Table 2 shows the frequency of samples detected by ELISA for ACE Level. While, Table 3 shows the sensitivity (Sn), specificity (Sp), positive predicative value (PPV), negative predictive value (NPV), accuracy, positive likelihood ratio, (PLR), negative likelihood ratio (NLR) and Diagnostic Index calculated for ACE level. At ACE value of $\mathbf{1 1 7 . 5}(\mathbf{n g} / \mathbf{m l})$, the sensitivity and NPV values were $\mathbf{8 2 . 2} \%$ \& $\mathbf{7 7 . 7 8} \%$ respectively, but the specificity $(\mathbf{7 0} \%)$ and PPV $(\mathbf{7 5 . 5 1} \%)$ decreased. In ROC analysis, the area under the receiver characteristic curve for ACE value $(\mathbf{0 . 7 6 1 + . 0 5 5 )}$ indicating a greater ability of ACE Values for distinguishing diabetic nephropathy from diabetic without nephropathy group (Figure 1). For diabetic nephropathy, positive and negative likelihood ratios (PLR, NLR) for serum ACE, showed small changes but there were no significant changes observed in the PLR and NLR with diabetic without nephropathy.

Figure 1: Receiver operating characteristic curve for ACE level (the area under the receiver characteristic curve for ACE value $(0.761+0.055), 95 \% \mathrm{Cl}: 65.4 \%-86.8 \%)$

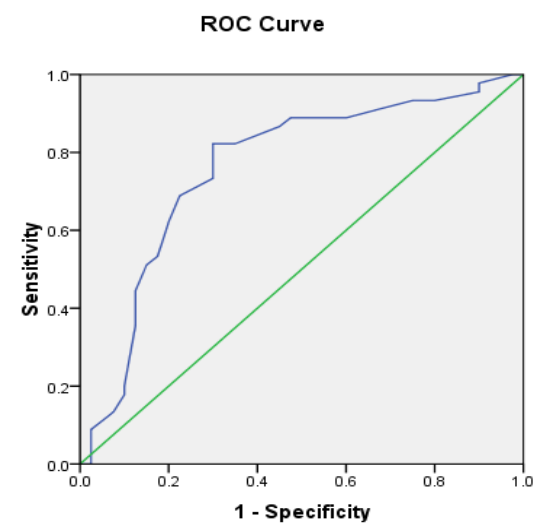

Diagonal segments are produced by ties. 
Table 2: Frequency of Samples detected by ELISA for ACE Level

\begin{tabular}{|c|c|c|c|}
\hline Parameter & $\begin{array}{c}\text { DM } \\
(\mathbf{n}=\mathbf{4 0})\end{array}$ & $\begin{array}{c}\text { DN } \\
(\mathbf{n}=\mathbf{4 5})\end{array}$ & P value \\
\hline $\begin{array}{c}\text { (ACE level) } \\
\text { Negative }(\mathrm{n}=36)\end{array}$ & 28 & 8 & 0.0001 \\
\hline $\begin{array}{c}\text { (ACE level) } \\
\text { Positive }(n=49\end{array}$ & 12 & 37 & \\
\hline
\end{tabular}

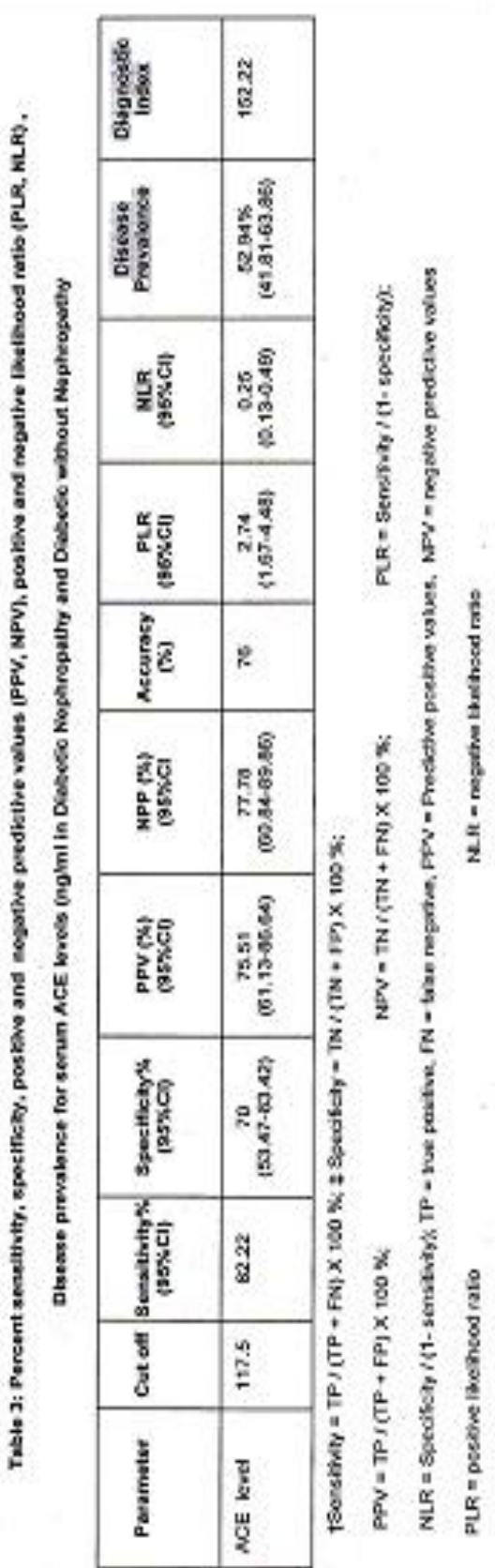

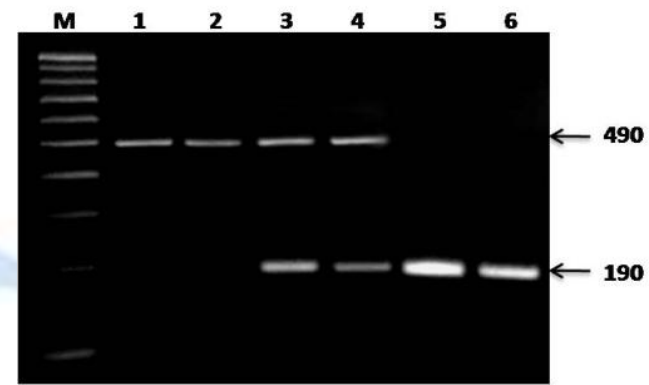

\subsection{Genotype distribution and allele frequencies of I/D polymorphism for the ACE gene}

ACE I/D polymorphism was assessed and is represented in Figure 2, with the 490 bp band indicating II genotype, 490 and 190 bp indicating ID genotype, and 190 bp indicating DD genotype. The distribution of ACE I/D genotype and its allele frequency for the studied groups are summarized in Table 4.

Figure 2: Detection of ACE (I/D) polymorphism by electrophoresis in a $2 \%$ agarose gel stained with Red-Safe.

The PCR products were visualized under UV light.

M: Molecular DNA marker (100-1000 bp)

Lanes 1, 2: II homozygous at $490 \mathrm{bp}$

Lanes 3,4: ID heterozygous at 490, $190 \mathrm{bp}$

Lanes 5, 6: DD homozygous at $190 \mathrm{bp}$

The results showed significantly higher DD genotype distribution and $D$ allele frequency in type 2 diabetes patients who progressed nephropathy than in control $(P=$ $0.035, P=0.008$, respectively) and type 2 diabetes without nephropathy $(P<0.001, P<0.001$, respectively). When the pure mutant DD genotype was pooled with ID and II, we found the DD genotype to be higher in the nephropathy group than in the control and diabetic groups. 
Table 4: Genotype distribution and allele frequencies of the ACE (I/D), gene polymorphism in the studied groups

\begin{tabular}{|c|c|c|c|c|c|}
\hline & $\begin{array}{l}\text { Control } \\
(n=45)\end{array}$ & $\begin{array}{c}\text { T2DM } \\
\text { without } \\
\text { nephropathy } \\
(n=40)\end{array}$ & $\begin{array}{c}\text { T2DM } \\
\text { with } \\
\text { nephropathy } \\
(n=45)\end{array}$ & $\mathbf{P}^{*}$ & $\mathbf{P}^{\star \star}$ \\
\hline $\begin{array}{c}\text { ACE Genotype } \\
\text { II }^{\mathrm{a}}\end{array}$ & $21(46.71 \%)$ & $10(25 \%)$ & 7 (15.6\%) & & \\
\hline ID & $18(40 \%)$ & $20(50 \%)$ & $13(28.9 \%)$ & 0.17 & 0.903 \\
\hline $\mathrm{DD}^{\mathrm{b}}$ & $6(13.3 \%)$ & $10(25 \%)$ & $25(55.6 \%)$ & $<0.001$ & 0.035 \\
\hline $\mathrm{DD}+\mathrm{ID}^{\mathrm{a}}$ & $24(53.3 \%)$ & $30(75 \%)$ & $38(84.4 \%)$ & 0.001 & 0.277 \\
\hline$I I+I D^{b}$ & $39(86.7 \%)$ & $30(75 \%)$ & $20(44.4 \%)$ & $<0.001$ & 0.004 \\
\hline $\begin{array}{c}\text { Allele } \\
\text { I }\end{array}$ & $60(66.7 \%)$ & $40(50 \%)$ & 27 (30\%) & & \\
\hline $\mathrm{D}$ & $30(33.3 \%)$ & $40(50 \%)$ & $63(70 \%)$ & $<0.001$ & 0.008 \\
\hline
\end{tabular}

Data are number (\%), variables were compared using chi square $\left(\mathrm{X}^{2}\right)$ test or Fischer's exact test.

a II vs ID+DD

${ }^{\mathrm{b}} \mathrm{DD}$ vs II+ID

${ }^{*} \mathrm{P}$ values for comparison between T2DM with nephropathy \& controls,

${ }^{* *} P$ values for comparison between T2DM with nephropathy \& T2DM without nephropathy.

Bold values indicate significant difference

$P$ value $<0.05$ was considered significant.

\subsection{Characteristics of diabetic nephropathy patients with different ACE genotypes}

Characteristics of diabetic nephropathy patients with different ACE genotypes are shown in Table 5 . The comparison revealed no significant differences in fasting plasma glucose, urinary total protein, urinary albumin levels, albumin creatinine ratio, diabetic duration, and insulin treatment among diabetic nephropathy patients with different ACE genotypes. Whereas, there was a significant association between elevated glycated hemoglobin, serum ACE level, poor diabetic control, and ACE DD pure mutant genotype.

Table 5: Characteristics of T2DM patients with and without nephropathy among different I/D genotypes on ACE gene

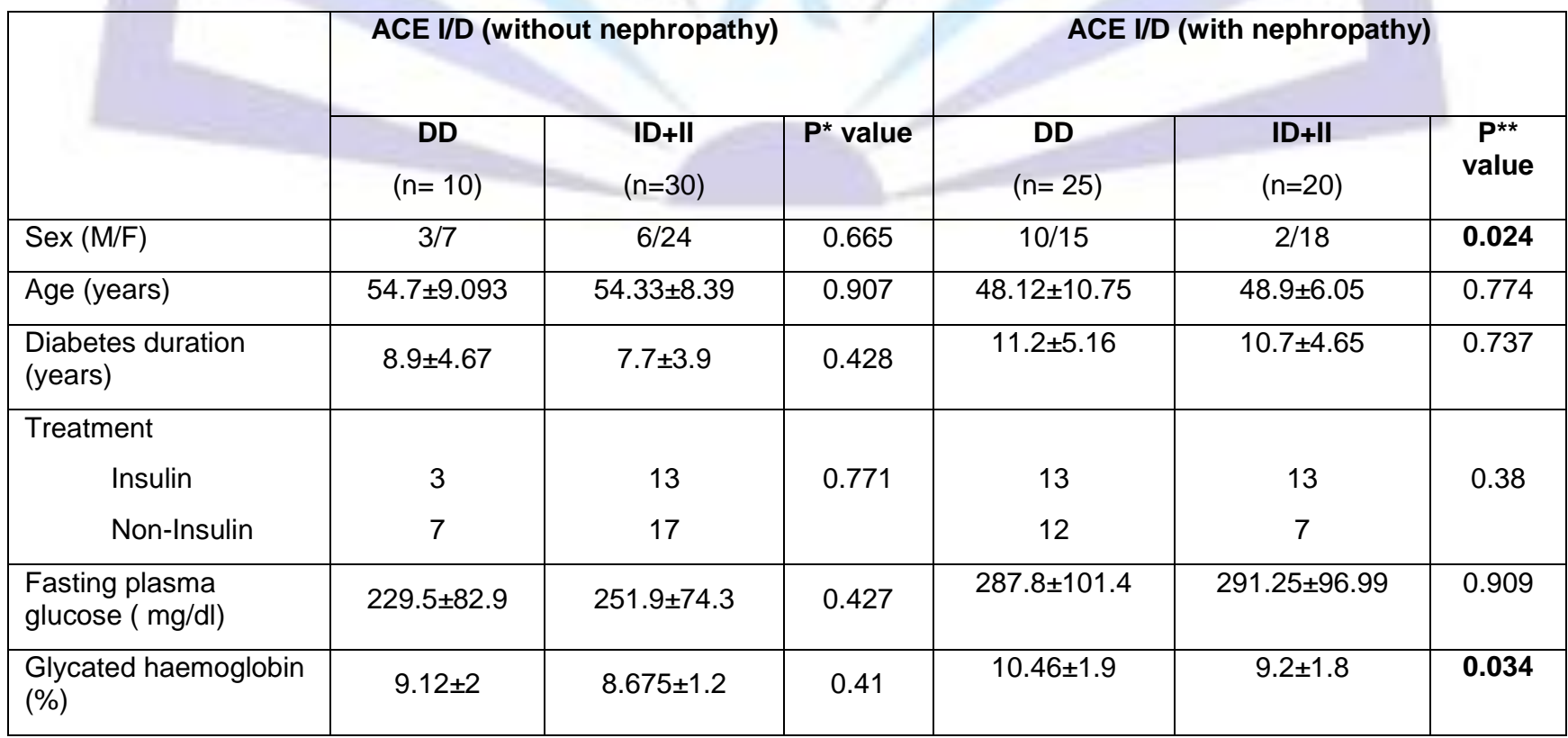




\begin{tabular}{|c|c|c|c|c|c|c|}
\hline \multicolumn{7}{|l|}{ Diabetic Control } \\
\hline Good & 7 & 19 & & 6 & 12 & 0.016 \\
\hline Fair & 1 & 9 & 0.215 & 2 & 3 & \\
\hline Poor & 2 & 2 & & 17 & 5 & \\
\hline $\begin{array}{l}\text { Urinary total protein } \\
(\mathrm{mg} / \mathrm{L})\end{array}$ & $92.95 \pm 43.3$ & $98.65 \pm 52.99$ & 0.761 & $459.4 \pm 139.5$ & $437.85 \pm 120.3$ & 0.587 \\
\hline Urinary-albumin (mg/L) & $9.81 \pm 7.7$ & $15.36 \pm 10.3$ & 0.129 & $91.7 \pm 77.99$ & $86.97 \pm 50.09$ & 0.815 \\
\hline Urinary creatinine $(g / L)$ & $1.24 \pm 0.48$ & $1.1 \pm 0.339$ & 0.353 & $0.91 \pm 0.39$ & $1.066 \pm .048$ & 0.246 \\
\hline $\begin{array}{l}\text { Albumin creatinine } \\
\text { ratio }(\mathrm{mg} / \mathrm{g})\end{array}$ & $9.2 \pm 7.3$ & $14.2 \pm 9.3$ & 0.129 & $118.5 \pm 119.5$ & $87 \pm 39.5$ & 0.266 \\
\hline $\begin{array}{l}\text { Serum ACE level } \\
(\mathrm{ng} / \mathrm{ml})\end{array}$ & $155.5 \pm 63.6$ & $101.8 \pm 25.8$ & $<0.001$ & $166.5 \pm 31.99$ & $128.3 \pm 38.99$ & 0.001 \\
\hline
\end{tabular}

Data are expressed as mean \pm SD for quantitative variable or number for qualitative one

One-way ANOVA and Chi square test were used to compare the clinical and laboratory characteristics of patients divided according to genotypes.

${ }^{*} \mathrm{P}$ values for comparison within T2DM without nephropathy group,

${ }^{* *} \mathrm{P}$ values for comparison within T2DM with nephropathy group.

Bold values indicate significant difference

$\mathrm{P}<0.05$ was considered significant.

\section{Discussion}

Diabetic nephropathy is the outcome of various pathophysiological processes, such as hydrodynamic alterations, metabolic abnormalities, various growth factors, and genetic factors. Genetic predisposition plays a role in the development of diabetic nephropathy, which clusters within families in both type 1 and type 2 diabetes.

Many of the previous studies of the association between ACE polymorphism and diabetic nephropathy yielded conflicting results. Several factors, including variations in ethnic background of the cases and controls, the possible criteria of inclusion and exclusion, and lack of statistical power due to small sample sizes, may be responsible for the contradictory results.

The ACE gene is one of the important genes in RAS pathway. To examine the effect of the ACE gene I/D polymorphism to develop nephropathy in T2DM patients, T2DM patients with nephropathy were compared with healthy non-diabetic control subjects and also compared with T2DM patients without nephropathy. The outcome was as follows: the DD genotype was significantly higher in DN than healthy non-diabetic control subjects and T2DM patients without nephropathy. Moreover, the frequency of the D allele was also higher in DN compared to healthy non-diabetic subjects and T2DM patients without nephropathy. This finding raises the suspicion that the $D$ allele or DD homozygous is accompanying with the progression of nephropathy in type 2 diabetic patients. These observations are in agreement with other previous studies, a meta-analysis of data from 18 studies, which included 14,108 diabetic nephropathy patients and 12,472 controls, reported significant association between the ACE I/D polymorphism and the risk of nephropathy for all genetic models ${ }^{[15]}$. A strong association between the ACE DD genotype and/or the D allele and the risk for nephropathy in type 2 diabetes was found in Malaysian, ${ }^{[16]}$; British Caucasian, ${ }^{[17]}$; Bahraini, ${ }^{[18]}$ and also in Japan ${ }^{[19]}$, USA ${ }^{[20]}$, and Iran

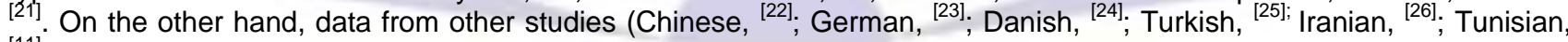
${ }^{[11]}$ ) failed to confirm an association of the ACE I/D gene polymorphism with diabetic nephropathy.

The data from India also show contradictory results. Viswanathan et al. ${ }^{[27]}$, Naresh et al. ${ }^{[28]}$ and Bhavani et al. ${ }^{[29]}$ show a positive association with the D allele (ID and DD genotypes) of the ACE polymorphism and diabetic nephropathy in their South Indian populations, whereas Bhaskar et al. ${ }^{[30]}$ in South Indian and Prasad et al. ${ }^{[31]}$ and Kumar et al. ${ }^{[32]}$ in North Indian populations found no relation between ACE polymorphism and development of nephropathy in type 2 diabetic patients. These conflicting results may be due to several factors, mainly ethnicity.

A meta-analysis of 47 studies published from 1994 to 2004, demonstrated that the II genotype has reduced the risk of DN compared to the D-allele carriers ${ }^{[33]}$. In fact, the deletion polymorphism is associated with elevated serum and cellular ACE levels ${ }^{[34 ; 35] .}$ The elevated ACE expression increases the plasma angiotensin II level, and promotes podocyte injury which leads to progressive kidney diseases as well as DN [36]. In the current study, there was a significant association between DD genotype of ACE gene and elevated serum ACE level.

In addition, the mutant DD genotype of ACE I/D polymorphism exhibited significant association with elevated glycated hemoglobin level and poor diabetic control.

Our study shows that other factors such as glycated hemoglobin, poor diabetic control, and serum ACE level are also responsible for development of diabetic nephropathy. 


\section{IN CONCLUSION,}

The present study supports the data that show the ACE I/D polymorphism may be used as a genetic risk factor for diabetic nephropathy in type 2 diabetes mellitus cases. As this study is limited with less number of cases and controls, the genotypic and allelic differences that observed may not represent a true association. Hence, additional studies considering gene-gene and gene-environment interactions should be investigated to estimate the overall risk of the ACE gene in the pathogenesis of diabetic nephropathy.

\section{Corresponding author}

- Esmat Ashour, e.mail. esmatashour3@yahoo.com

\section{Competing interests}

- The authors declare that they have no competing interests.

\section{Authors' contributions}

- WG and HM: collected samples and provided clinical data, contributed to data analysis and interpretation and wrote the manuscript.

- OGS: performed the lab analysis, contributed to data analysis and interpretation.

- EA, MA: provided clinical data, identified patients, contributed to statistical data analysis and reviewed the manuscript.

- MFI, EA: conceived, designed and supervised the study and reviewed the manuscript and: had the initial idea and helped write the manuscript. All authors read and approved the final manuscript.

\section{Acknowledgments}

This work was supported by grants from the National Research Centre ,Dokki, Giza, Egypt. We thank the patients who participated in this study.

\section{REFERENCES}

[1] Movva S., Alluri R.V., Komandur S., Vattam K., Eppa K., Mukkavali K.K., Mubigonda S., Saharia S., Shastry J.C. \& Hasan Q. (2007). Relationship of angiotensin-converting enzyme gene polymorphism with nephropathy associated with Type 2 diabetes mellitus in Asian Indians. J Diabetes Complications. 21(4) 237-241.

[2] Hamed SA, Amine NF, Galal GM, Helal SR, Tag El-Din LM, Shawky OA, Abdel Rahman MS. (2008). Vascular risks and complications in diabetes mellitus: the role of helicobacter pylori infection. J Stroke Cerebrovask Dis. 17(2):8694.

[3] White K.E. \& Bilous R.W. (2000). Type 2 diabetic patients with nephropathy show structural-functional relationships that are similar to type 1 disease. J Am Soc Nephrol. 11(9) 1667-1673.

[4] Mogensen C.E. \& Christensen C.K. (1984). Predicting diabetic nephropathy in insulin dependent patients. N Engl J Med. 311(2) 89-93.

[5] Chowdhury TA, Dyer PH, Kumar S, Barnett AH, Bain SC. (1999). Genetic determinants of diabetic nephropathy. Clin Sci 96:221-230.

[6] Freedman BI, Tuttle AB, Spray BJ. (1995). Familial predisposition to nephropathy in African-Americans with noninsulindependent diabetes mellitus. Am J Kidney Dis. 25: 710-3.

[7] Rigat B., Hubert C., Corvol P. \& Soubrier F. (1992). PCR detection of the insertion/deletion polymorphism of the human angiotensin converting enzyme gene (DCP1) (dipeptidyl carboxypeptidase 1). Nucleic Acids Res. 20(6):1433.

[8] Rigat B., Hubert C., Alhenc-Gelas F., Cambien F., Corvol P. \& Soubrier F. (1990). An insertion/deletion polymorphism in the angiotensin I-converting enzyme gene accounting for half the variance of serum enzyme levels. $J$ Clin Invest. 86(4): 1343-1346.

[9] Hadjadj S., Gallois Y., Alhenc-Gelas F., Chatellier G., Marre M., Genes N ., Lievre M., Mann J., Menard J. \& Vasmant D. (2003). Angiotensin-l-converting enzyme insertion/deletion polymorphism and high urinary albumin concentration in French Type 2 diabetes patients. Diabet. Med. 20(8):677-682.

[10] Khan M.K., Parimala N., Ishaq M. \& Siraj M. (2011). ACE I/D gene polymorphism in diabetic nephropathy: Clinical implications. J Medical \& Allied Sc. 1(1): 42-45.

[11] Arfa I. , Abid A., Nouira S., Elloumi-Zghal H., Malouche D., Mannai I. , Zorgati MM., Ben Alaya N. , Rebai A., Zouari B., Ben Ammar S., Ben Rayana MC., Hmida S., Blousa-Chabchoub S. \& Abdelhak S. (2008). Lack of 
association between the angiotensin-converting enzyme gene (I/D) polymorphism and diabetic nephropathy in Tunisian type 2 diabetic patients. J Renin Angiotensin Aldosterone Syst. 9(1):32- 36.

[12] Singh P.P., Naz I., Gilmour A., Singh M. \& Mastana S. (2006). Association of APOE (Hha1) and ACE (I/D) gene polymorphisms with type 2 diabetes mellitus in North West India. Diabetes Res Clin Pract. 74(1):95-102.

[13] Al-Harbi E.M., Farid E.M., Gumaa K.A., Masuadi E.M. \& Singh J. (2011). Angiotensin-converting enzyme gene polymorphisms and T2DM in a case-control association study of the Bahraini population. Mol Cell Biochem. 350(12):119-125.

[14] Shanmugam V., Sell K.W. \& Saha B.K. (1993). Mistyping ACE heterozygotes. PCR Methods Appl. 3(2):120-121.

[15] Wang F, Fang Q, Yu N, Zhao D, Zhang Y, Wang J, Wang Q, Zhou X, Cao X, Fan X. (2012). Association between genetic polymorphism of the angiotensin-converting enzyme and diabetic nephropathy: ameta-analysis comprising 26,580 subjects. J Renin Angiotensin Aldosterone Syst 13(1):161-174

[16] Ramachandran V., Ismail P., Stanslas J., Stanslas J., Shamsudin N., Moin S. \& Mohd Jas R. (2008). Association of insertion/deletion polymorphism of angiotensin-converting enzyme gene with essential hypertension and type 2 diabetes mellitus in Malaysian subjects. J. Renin Angiotensin Aldosteron Syst. 9(4):208-214.

[17] Stephens J.W., Dhamrait S.S., Cooper J.A., Acharya J., Miller G.J., Hurel S.J. \& Humphries S.E.. (2005). The D allele of the ACE I/D common gene variant is associated with Type 2 diabetes mellitus in Caucasian subjects. Mol Genet Metab. 84:83-89.

[18] Al-Harbi E.M., Farid E.M., Gumaa K.A. \& Singh J. (2012). Genotypes and allele frequencies of Angiotensinconverting enzyme gene (ACE) insertion/deletion polymorphisms among Bahraini population with type 2 diabetes mellitus and related diseases. Mol Cell Biochem. 362:219-223.

[19] Kotani K., Fujiwara S., Tsuzaki K., Sano Y., Matsuoka Y., Hamad T. \& Sakane N.( 2009). An association between angiotensin II type 2 receptor gene A/C3123 polymorphism and glycemic control marker in a general Japanese population. Mol Biol Rep. 36(5) 917-920.

[20] Jeffers BW, Estacio RO, Raynolds MV, Schrier RW. (1997). Angiotensin-converting enzyme gene polymorphism in non-insulin dependent diabetes mellitus and its relationship with diabetic nephropathy. Kidney Int 52(2):473-477

[21] Nikzamir A., Esteghamati A., Feghhi M., Nakhjavani M., Rashidi A. \& Reza J.Z. (2006). Angiotensin converting enzyme gene polymorphism in Iranian patients with type II diabetes. Iran. J Immunol. 3:23-29.

[22] Wong TY, Chan JC, Poon E, Li PK. (1999). Lack of association of angiotensin-converting enzyme (DD/II) and angiotensinogen M235T gene polymorphism with renal function among Chinese patients with type II diabetes. Am J Kidney Dis 33:1064-1070

[23] Schmidt S., Strojek K., Grzeszczak W., Bergis K. \& Ritz E. (1997). Excess of DD homozygotes in haemodialysed patients with type II diabetes. The Diabetic Nephropathy Study Group. Nephrol Dial Transplant. 12(3):427-429.

[24] Tarnow L, Cambien F, Rossing P, Nielsen FS, Hansen BV, Lecerf L, Poirier O, Danilov S, Parving HH. (1995). Lack of relationship between an insertion/deletion polymorphism in the angiotensin I-converting enzyme gene and diabetic nephropathy and proliferative retinopathy in IDDM patients. Diabetes 44:489-494

[25] Degirmenci I., Kebapci N., Basaran A., Efe B., Gunes H.V., Akalin A., Kurt H., Urhan M. \& Demirustu C. (2005). Frequency of angiotensin-converting enzyme gene polymorphism in Turkish type 2 diabetic patients. Int $\mathrm{J}$ Clin Pract. 59(10):1137-1142.

[26] Rahimi Z, Felehgari V, Rahimi M, Mozafari H, Yari K, Vaisi-Raygani A, Rezaei M, Malek-Khosravi S, Khazaie H. (2011). The frequency of factor $V$ Leiden mutation, ACE gene polymorphism, serum ACE activity and response to ACE inhibitor and angiotensin II receptor antagonist drugs in Iranians type II diabetic patients with microalbuminuria. Mol Biol Rep 38:2117-2123

[27] Viswanathan V., Zhu Y., Bala K., Dunn S., Snehalatha C., Ramachandran A., Jayaraman M. \& Sharma K. (2001). Association between ACE gene polymorphism and diabetic nephropathy in South Indian patients. JOP. 2(2):83-87.

[28] Naresh VV, Reddy AL, Sivaramakrishna G, Sharma PV, Vardhan RV, Kumar VS.(2009). Angiotensin converting enzyme gene polymorphism in type II diabetics with nephropathy. Indian J Nephrol. 19(4):145-148.

[29] Bhavani BA, Padma T, Sastry BKS, Reddy NK, Nausheen K. (2005). The insertion I/deletion D polymorphism of angiotensin-converting enzyme (ACE) gene increase the susceptibility to hypertension and/or diabetes. Int $\mathrm{J}$ Hum Genet 5(4):247-252

[30] Bhaskar L., Mahin S., Ginila RG., Soundararajan P.(2013). Role of the ACE ID and PPARG P12A Polymorphisms in Genetic Susceptibility of Diabetic Nephropathy in a South Indian Population. Nephro Urol Mon. 5(3):813-7.

[31] Prasad P., Tiwari AK., Kumar KM., Ammini AC., Gupta A., Gupta R., Sharma A.K., Rao A.R , Nagendra R. , Chandra T.S., Tiwari S.C., Rastogi P., Gupta B.L. \& Thelma B.K. (2006). Chronic renal insufficiency among Asian Indian with type II diabetes: Role of RAS gene polymorphisms. BMC Medical Genetics. 7:1-9. 
[32] Kumar R., Sharma RK., Agarwal S. (2013). Genetic Predisposition for Development of Nephropathy in Type 2 Diabetes Mellitus. Biochem Genet. 51:865-875

[33] Ng DP, Tai BC, Koh D, Tan KW, Chia KS.(2005). Angiotensin-I converting enzyme insertion/deletion polymorphism and its association with diabetic nephropathy: a meta-analysis of studies reported between 1994 and 2004 and comprising 14,727 subjects. Diabetologia. 48(5):1008-16.

[34] Eleni S, Dimitrios K, Vaya P. (2008). Angiotensin-I converting enzyme gene and I/D polymorphism distribution in the Greek population and a comparison with other European populations. J Genetics 87:91-93.

[35] Zhou JB, Yang JK, Lu JK (2010). Angiotensin-converting gene polymorphism is associated with type 2 diabetes: a meta-analysis. Mol Biol Rep 37:67-73.

[36] Das KJ, Sharma P, Naswa N, Soundararajan R, Kumar R, Bal C.(2012). Hybrid SPECT-CT with 99mTc-labeled red blood cell in a case of blue rubber bleb nevus syndrome: added value over planar scintigraphy. Diagn Interv Radiol19(1):41-3. 